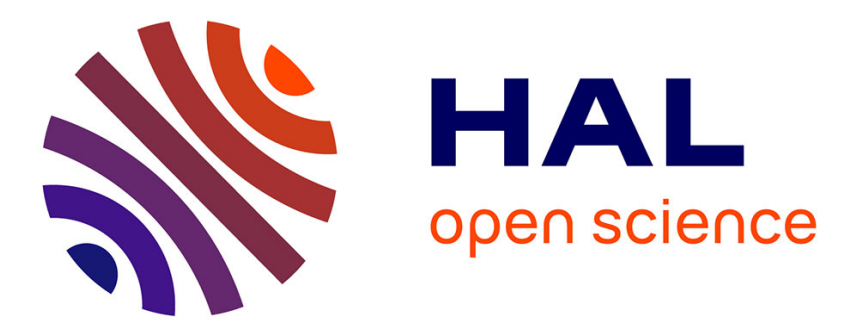

\title{
Long-circulating DNA lipid nanocapsules as new vector for passive tumor targeting.
}

\author{
Marie Morille, Tristan Montier, Pierre Legras, Nathalie Carmoy, Priscille
}

Brodin, Bruno Pitard, Jean-Pierre Benoît, Catherine Passirani

\section{- To cite this version:}

Marie Morille, Tristan Montier, Pierre Legras, Nathalie Carmoy, Priscille Brodin, et al.. Longcirculating DNA lipid nanocapsules as new vector for passive tumor targeting.. Biomaterials, 2010, 31 (2), pp.321-9. 10.1016/j.biomaterials.2009.09.044 . inserm-00491402

HAL Id: inserm-00491402 https://www.hal.inserm.fr/inserm-00491402

Submitted on 11 Jun 2010

HAL is a multi-disciplinary open access archive for the deposit and dissemination of scientific research documents, whether they are published or not. The documents may come from teaching and research institutions in France or abroad, or from public or private research centers.
L'archive ouverte pluridisciplinaire HAL, est destinée au dépôt et à la diffusion de documents scientifiques de niveau recherche, publiés ou non, émanant des établissements d'enseignement et de recherche français ou étrangers, des laboratoires publics ou privés. 


\section{LONG-CIRCULATING DNA LIPID NANOCAPSULES AS NEW VECTOR FOR PASSIVE TUMOR}

\section{TARGETING}

Morille M. ${ }^{1}$, Montier T. ${ }^{2}$, Legras P. ${ }^{3}$, Carmoy N. ${ }^{2}$, Brodin P. ${ }^{4}$, Pitard B. ${ }^{5,6}$, Benoit J-P. ${ }^{1}$ and Passirani

$\mathrm{C}^{1^{*}}$

${ }^{1}$ Inserm U646, Université d'Angers, 10 rue André Boquel, F-49100 Angers, France; ${ }^{2}$ INSERM U613, IFR 148 SclnBloS, Université de Bretagne Occidentale, 46 rue Félix Le Dantec, CS 51819, 29218 Brest Cedex 2, France; ${ }^{3}$ Service Commun d'Animalerie Hospitalo-Universitaire, Faculté de Médecine, F-49100 Angers, France; ${ }^{4}$ Institut Pasteur Korea, 39-1 Hawolgok-dong, Seongbuk-gu, Seoul, 136-791, Korea; ${ }^{5}$ Inserm U915, F-44000 Nantes, France; ${ }^{6}$ Université de Nantes, Faculté de Médecine, Institut du Thorax, F-44000 Nantes, France.

*Corresponding author. Tel.: +33241 735850. Fax: +33241735853.

E-mail: catherine.passirani@univ-angers.fr 


\section{Abstract}

Systemic gene delivery systems are needed for therapeutic application to organs that are inaccessible by percutaneous injection. Currently, the main objective is the development of a stable and non-toxic vector that can encapsulate and deliver foreign genetic material to target cells. To this end, DNA, complexed with cationic lipids i.e DOTAP/DOPE, was encapsulated into lipid nanocapsules (LNCs) leading to the formation of stable nanocarriers (DNA LNCs) with a size inferior to $130 \mathrm{~nm}$. Amphiphilic and flexible poly (ethylene glycol) (PEG) polymer coatings [PEG lipid derivative (DSPE-mPEG 2000 ) or F108 poloxamer] at different concentrations were selected to make DNA LNCs stealthy. Some of these coated lipid nanocapsules were able to inhibit complement activation and were not phagocytised in vitro by macrophagic THP-1 cells whereas uncoated DNA LNCs accumulated in the vacuolar compartment of THP-1 cells. These results correlated with a significant increase of in vivo circulation time in mice especially for DSPE-mPEG ${ }_{2000} 10 \mathrm{mM}$ and an early half-life time ( $\mathrm{t}_{1 / 2}$ of distribution) 5 -fold greater than for non-coated DNA LNCs (7.1h vs $1.4 \mathrm{~h})$. Finally, a tumor accumulation assessed by in vivo fluorescence imaging system was evidenced for these coated LNCs as a passive targeting without causing any hepatic damage.

Keywords: poly (ethylene glycol) - non-viral vector - stealth properties - blood circulation - tumor accumulation - EPR effect 


\section{1 - Introduction}

For the treatment of unreachable organs and disseminated or metastatic cancer, it is now essential to develop intravenous forms of gene therapy. However, systemic targeting remains a real challenge. Synthetic vectors based on the use of cationic lipids or polymers associated to DNA appear to have promising potential, given the safety problems encountered with viral vectors. Nevertheless, the systemic injection of these synthetic carriers usually results in a toxic response linked to their strong positive charge, incompatible with clinical applications [1].

Furthermore, when injected intravenously, colloidal carriers are rapidly cleared by the mononuclear phagocyte system (MPS) mainly represented by Kupffer cells in the liver and spleen macrophages. The recognition of the carriers by macrophages usually occurs through specific recognition by cellular receptors specific for plasma proteins that have been adsorbed at the vector surface. Among them, the C3 protein of the complement system plays a major role in the immune system's recognition of foreign particles [2]. The concept of modifying the surface of vectors has therefore been applied in order to decrease the opsonisation process and the specific or non-specific recognition by MPS and blood components [3].

Heurtault et al.[4] developed lipid nanocapsules synthesised by a solvent-free method and covered by $\mathrm{PEG}_{660}$ at high density, leading to really weak complement activation and low macrophage uptake $[3,5]$. In a previous work, the formulation of these nanocapsules was adapted to obtain DNA nanocapsules (DNA LNCs) [6]. Thanks to the use of oleic Plurol ${ }^{\circledR}$ instead of Lipoid $^{\circledR}$ in their formulation, the lipid core allowed the entrapment of plasmid DNA molecules via the formation of lipoplexes (cationic liposomes of DOTAP:DOPE complexed with plasmid DNA). DNA LNCs were small (117 $\pm 10 \mathrm{~nm})$, suitable for an intravenous injection, but in vivo stability and blood half-life remained low and were ill-adapted to efficient in vivo transfection [6].

To allow an extended circulation time, and consequently a higher tumor selectivity by passive accumulation through the EPR (enhanced permeability and retention) effect [7], we chose to modify the surface of our gene delivery systems, by inserting longer PEG chains at the surface of DNA LNCs between the already-existing, dense $\mathrm{PEG}_{660}$ chains. This was carried out through the use of two kinds of amphiphilic and flexible polymers. The first one was F108 block copolymer, consisting of ethylene 
oxide (EO) and propylene oxide (PO) blocks arranged in a triblock structure $\left(\mathrm{EO}_{132}-\mathrm{PO}_{50}-\mathrm{EO}_{132}\right)$. This kind of amphiphilic polymer recently demonstrated great promise for the delivery of pDNA, thanks to its proven in vivo transfection efficiency [8-11]. The second one was a lipid PEG derivative, 1,2distearoyl-sn-glycero-3-phosphoethanolamine-N-[methoxy(polyethyleneglycol)-2000]

(DSPE$\left.\mathrm{mPEG}_{2000}\right)$. The ability of the different particles to escape complement activation and uptake by THP-1 macrophages was investigated. Then the long-circulating properties of these particles in vivo after intravenous injection in mice and their tumor accumulation ability by NIR fluorescence imaging system were evaluated. In parallel, blood samples were harvested to measure the hepatotoxic impact of the different formulations before and after injection. 


\section{2 - Materials and methods}

\section{1 - Preparation of the nano-colloids}

\subsection{1 - Liposomes}

DOTAP (1,2-DiOleoyl-3-TrimethylAmmonium-Propane) and DOPE (1,2-DiOleyl-sn-glycero-3PhosphoEthanolamine) (Avanti Polar Lipids, Inc, Alabaster, USA) were first dissolved in chloroform (Sigma, Saint-Quentin Fallavier, France) and then dried by an evaporation process under vacuum. The formed lipid film was hydrated with deionized water. Then liposomes were sonicated for 20 minutes. Lipoplexes were prepared by mixing DOTAP/DOPE (1/1, M/M) liposomes with $660 \mu \mathrm{g}$ of luciferase-encoding plasmid [10] (pgWIZ-luciferase amplified and research grade purified by GENEART, Regensburg, Germany) at a charge ratio of $5(+/-)$ in $150 \mathrm{mM} \mathrm{NaCl}$.

\subsection{2 - DNA-loaded lipid nanocapsules (DNA LNCs)}

The formulation of LNCs was based on a phase-inversion process described by Heurtault et al.[12]. LNCs were composed of lipophilic Labrafac ${ }^{\circledR}$ WL 1349 (caprylic-capric acid triglycerides, European Pharmacopeia, IVth, 2002) and oleic Plurol ${ }^{\circledR}$ (Polyglyceryl-6 dioleate) which were kindly provided by Gatefossé S.A. (Saint-Priest, France) and Solutol ${ }^{\circledR}$ HS-15 (30\% of free polyethylene glycol 660 and $70 \%$ of polyethylene glycol 660 hydroxystearate (HS-PEG) European Pharmacopeia, IVth, 2002) which was a gift from BASF (Ludwigshafen, Germany). Briefly, $3.9 \%$ of oleic Plurol ${ }^{\circledR}$ (w/w), 5.9 $\%$ of Solutol $^{\circledast}(\mathrm{w} / \mathrm{w}), 9.9 \%$ of $\operatorname{Labrafac}^{\circledast}(\mathrm{w} / \mathrm{w}), 78.9 \%$ of water $(\mathrm{w} / \mathrm{w})$ and $1.4 \%$ of $\mathrm{NaCl}$, were mixed together under magnetic stirring. DNA LNCs were synthesized as already described[6]. Fluorescent lipid nanocapsules (Dil or DiD empty LNCs and Dil or DiD DNA LNCs) were obtained by a previouslydescribed method [13]. Briefly, 1,1'-dioctadecyl-3,3,3',3'-tetramethylindocarbocyanine perchlorate (Dil, emission wavelength $($ em. $)=549 \mathrm{~nm}$; excitation wavelength $($ exc. $)=565 \mathrm{~nm}$ ) or 1,1'-dioctadecyl$3,3,3^{\prime}, 3^{\prime}$-tetramethylindodicarbocyanine perchlorate $(\mathrm{DiD}, \mathrm{em} .=644 \mathrm{~nm}$; exc. $=665 \mathrm{~nm})($ Invitrogen, Cergy Pontoise, France) was dissolved in acetone at $6 \%(\mathrm{w} / \mathrm{w})$ and the resulting Dil or DiD stock solution was incorporated in $\operatorname{Labrafac}^{\circledR}(1: 10(w / w))$. Finally, acetone was evaporated before use.

\subsection{3 - Preparation of coated nanocapsules by post-insertion}


Two kinds of polymers were used for post-insertion: 1,2-DiStearoyl-sn-glycero-3PhosphoEthanolamine-N-[methoxy(polyethyleneglycol)-2000] (DSPE-mPEG ${ }_{2000}$ ) (Mean Molecular Weight $(\mathrm{MMW})=2,805 \mathrm{~g} / \mathrm{mol}) \quad\left(\right.$ Avanti Polar Lipids, Inc, Alabaster, USA) or Pluronic ${ }^{\circledR} \mathrm{F} 108$ $(\text { Poly(ethyleneoxide })_{132}$-poly(propyleneoxide $)_{50}$-poly(ethyleneoxide $\left.)_{132}\right)(\mathrm{MMW}=14,600 \mathrm{~g} / \mathrm{mol})$ kindly provided by BASF. These polymers were added to LNCs in order to obtain a final concentration of 2, 5 and $10 \mathrm{mM}$ for DSPE-mPEG 2000 and 1, 2, $3 \mathrm{mM}$ respectively for F108. Prior to the post-insertion, the LNCs were purified thanks to the use of PD10 Sephadex columns (Amersham Biosciences Europe, Orsay, France) and then concentrated by ultrafiltration with Millipore Amicon ${ }^{\circledR}$ Ultra-15 centrifugal filter devices (Millipore, St Quentin-Yvelines, France). This purification step providing a desalting effect, the salt concentration of the suspension was therefore adapted to obtain a physiologic concentration of $\mathrm{NaCl}(150 \mathrm{mM})$. Pre-formed LNCs and DSPE-mPEG 2000 or F108 micelles were co-incubated for $4 \mathrm{~h}$ at $30^{\circ} \mathrm{C}$. The mixture was vortexed every 15 minutes and then quenched in an ice bath for 1 minute. To provide controls, the same thermal treatments were applied to LNC suspensions without polymers.

\subsection{4 - Polymethyl methacrylate nanoparticles (PMMA NP)}

Polymethyl methacrylate (PMMA) nanoparticles were synthesized by the polymerisation of methyl methacrylate (MMA, Merck, Hohenbrunn, Germany) as described previously[14]. To obtain fluorescent PMMA NPs, the pre-formed PMMA particles were allowed to swell in methanol during an incubation period of $2 \mathrm{~h}$ at room temperature with Dil dissolved in acetone. The water-insoluble Dil diffused into the PMMA nanoparticles and was entrapped when the solvent was removed through the evaporation process, for $30 \mathrm{~min}$. at $70^{\circ} \mathrm{C}$.

\section{2 - Characterisation of the nanoparticles}

\subsection{1 - Physico-chemical characteristics of coated DNA LNCs}

The average hydrodynamic diameter and the polydispersity index (PI) of the LNCs were determined by dynamic light scattering (DLS) using a Malvern Zetasizer ${ }^{\circledR}$ (Nano Series DTS 1060, Malvern Instruments S.A., Worcestershire, UK). A 1:100 dilution of the nanoparticle in deionized water was processed and size measurement was performed at $25^{\circ} \mathrm{C}$ (in triplicate). The measure of zeta 
potential was achieved on nanoparticle suspensions at $150 \mathrm{mM} \mathrm{NaCl}$ diluted in deionized water at $1: 100$, providing a final salt concentration of $1,5 \mathrm{mM}$.

\subsection{2 - DNA stability study}

The stability of nanocapsule suspensions during storage at $4^{\circ} \mathrm{C}$ was assessed by measuring the size distribution. The stability was also tested after centrifugation at $15,000 \mathrm{~g}$ at room temperature for $20 \mathrm{~min}$ in order to visualize any demixing among the components. The stability of encapsulation and the integrity of DNA molecules after the process of nanocapsule formulation, and post-insertion were evaluated by agarose gel electrophoresis. A volume of LNCs or lipoplexe suspension equivalent to $0.2 \mu \mathrm{g}$ of DNA before and after treatment with Triton $^{\circledR}$ 100X (Sigma, Saint-Quentin Fallavier, France) was mixed with gel-loading solution (Sigma, Saint-Quentin Fallavier, France) and deposited in each well of $1 \%$ agarose gel containing ethidium bromide (Sigma, Saint-Quentin Fallavier, France). Controls were constituted by using $0.2 \mu \mathrm{g}$ of free DNA in solution or associated to cationic lipids. Samples were migrated $20 \mathrm{~min}$ at $100 \mathrm{~V}$ in a Tris- EDTA buffer.

\section{3 - Macrophage uptake evaluation}

\subsection{1 - Cell culture}

THP-1 cells (human monocyte/macrophage cell line obtained by ATCC, Manassas, VA, USA) were grown in suspension in a humidifier-incubator $\left(5 \% \mathrm{CO}_{2}\right)$ at $37^{\circ} \mathrm{C}$ in ATCC suggested medium. Cells were cultured in the same medium with 200mM Phorbol 12-myristate 13-acetate (PMA, Sigma, Saint-Quentin Fallavier, France) for $24 \mathrm{~h}$ to allow adherence and differentiation [15]. The medium was then aspired (to eliminate non-adhered cells) and the cells were subsequently incubated in a new medium for an additional $24 \mathrm{~h}$ prior to uptake studies. Cells were harvested and counted using Trypan blue exclusion assay with a haemacytometer. Cells $\left(0.6 \times 10^{6} / \mathrm{ml}\right)$ were plated on sterile, 24-well cell culture clusters, and then allowed to grow for $24 \mathrm{~h}$ at $37^{\circ} \mathrm{C}$.

\subsection{2 - Cytotoxicity assay}

The 24-well plates were exposed to different suspensions (free DNA, free lipoplexes, empty LNCs, and DNA LNCs, at a DNA concentration equivalent to the DNA LNCs one, excepted for empty 
LNCs). Nanoparticles were prepared at a DNA concentration of $446 \mu \mathrm{g} / \mathrm{ml}$ and 1:10 cascade dilutions were performed in culture $(44.6,4.46$ and $0.446 \mu \mathrm{g} / \mathrm{ml}$ ). After $48 \mathrm{~h}$ of exposure, cell viability was determined by the MTT test performed in triplicate according to the procedure described by Mosmann [16]. Briefly, $40 \mu \mathrm{l}$ of MTT solution at $5 \mathrm{mg} / \mathrm{ml}$ in phosphate-buffered saline (PBS) $1 \mathrm{X}$ was added to each well, and then the plates were incubated at $37{ }^{\circ} \mathrm{C}$ fo $\mathrm{r} 4 \mathrm{~h}$. The medium was removed and $200 \mu \mathrm{l}$ of $0.06 \mathrm{~N}$ acid-isopropanol was added to each well and mixed thoroughly to completely dissolve the dark blue crystals. The optical density was measured at 580nm using a Microplate reader Multiskan Ascent (Thermo Fisher Scientific, Cergy-Pontoise, France).

\subsection{3 - Internalization study by cellular imaging}

Cells were incubated with a series of 2-fold dilutions of Dil-labelled LNC suspensions starting from 1/100. After 20min or 24h, macrophages were stained with Syto60 (Invitrogen, Cergy Pontoise, France). Confocal images were recorded on an automated fluorescent confocal microscope Opera ${ }^{\mathrm{TM}}$ (PerkinElmer) using a 20X-water objective (NA 0.70). Dil-labelled LNCs were detected using a 532nm laser coupled with a 565/50nm detection filter (green channel) and cells labelled with Syto 60 were identified with a $635 \mathrm{~nm}$ laser coupled with a 690/40nm detection filter (red channel). Four independent pictures were taken for each plate well and each image was then processed in order to quantify the number of green LNCs and cells.

\section{4 - Complement activation study}

Complement consumption was assessed in normal human serum (NHS) (provided by the Etablissement Francais du Sang, CHU, Angers, France) by measuring the residual haemolytic capacity of the complement system after contact with the different particles[2]. The technique consisted in determining the amount of serum able to lyse $50 \%$ of a fixed number of sensitized sheep erythrocytes with rabbit anti-sheep erythrocyte antibodies $(\mathrm{CH} 50)$, according to the procedure described elsewhere [5]. Complement activation was expressed as a function of the surface area in order to compare particles with different mean diameters. Nanoparticle surface areas were calculated as described elsewhere[14], using the equation: $S=n 4 \pi r^{2}$ and $V=n(4 / 3)\left(\pi r^{3}\right)$ leading to $S=3 m / r p$ where $\mathrm{S}$ is the surface area $\left(\mathrm{cm}^{2}\right)$ and $\mathrm{V}$ the volume $\left(\mathrm{cm}^{3}\right)$ of $n$ spherical beads of average radius $r$ 
$(\mathrm{cm}), m$ the weight $(\mu \mathrm{g})$ and $\rho$ the volumetric mass $\left(\mu \mathrm{g} / \mathrm{cm}^{3}\right)$. All experiments were performed in triplicate and a t-test of non-matched samples was used to test for the statistical significance of the results.

\section{5 - In vivo hepato-toxicity study after IV injection}

Blood samples $(\sim 200 \mu \mathrm{L})$ were collected from the saphenous vein of the mice on a heparin tube before and $24 \mathrm{~h}$ after administration. Tubes were then centrifuged at $10000 \times \mathrm{g}$ for $2 \mathrm{~min}$ at $+4{ }^{\circ} \mathrm{C}$ and plasma were harvested to measure the activity of the ALAT (alanine amino transferase) and ASAT (aspartate aminotransferase) enzymes. For ALAT measurements, two solutions were needed $(\mathrm{S} 1=$ Tris buffer at $\mathrm{pH}$ 7.5: 125mmol/L ; L-aspartate: $680 \mathrm{mmol} / \mathrm{L} ; \mathrm{LDH}>2000 \mathrm{U} / \mathrm{L}$ and $\mathrm{S} 2=\alpha-$ cetoglutarate $97 \mathrm{mmol} / \mathrm{L}$; NADH $1.1 \mathrm{mmol} / \mathrm{L})$. First, $200 \mu \mathrm{L}$ of $\mathrm{S} 1$ were mixed with $50 \mu \mathrm{L}$ of $\mathrm{S} 2$ during 20 sec. Then, $25 \mu \mathrm{L}$ of plasma were added to the mixture. After $50 \mathrm{sec}$ of incubation at room temperature, the absorbance at $340 \mathrm{~nm}$ was measured immediately and $60 \mathrm{sec}$ later. The ALAT activity was expressed in $U \mathrm{I} / \mathrm{L}$ and resulted of the product between the variation of the absorbance $(\Delta \mathrm{A} / \mathrm{min})$ and a coefficient $\sigma\left[\sigma=\left(\right.\right.$ final volume in $\left.\mathrm{mL}{ }^{*} 1000\right) /($ serum volume in $\mathrm{mL}$ * length of the optical distance * 6.3) (6.3 corresponding to the absorption of $\mathrm{NADH}$ at $340 \mathrm{~nm})$ ]. Here, the $\sigma$ coefficient was equal to 1746. For ASAT evaluation, the protocol was the strictly same, except that solutions S1 and S2 have been adapted $(\mathrm{S} 1=$ Tris buffer at $\mathrm{pH}$ 7.8: $100 \mathrm{mmol} / \mathrm{L}$; L-aspartate: $330 \mathrm{mmol} / \mathrm{L}$; LDH> $2000 \mathrm{U} / \mathrm{L}$; $\mathrm{MDH}>1000 \mathrm{U} / \mathrm{L}$ and $\mathrm{S} 2=\alpha$-cetoglutarate $78 \mathrm{mmol} / \mathrm{L} ; \mathrm{NADH} 1.1 \mathrm{mmol} / \mathrm{L})$. The measurements of the ALAT and ASAT transaminases released into the serum reflected the toxicity, notably the hepatological impact, of the various formulations. Our method adapted for small blood volume allowed performing a kinetic of the transaminase activity on each animal, limiting the device induced by interindividual variations that resulted from the techniques that required sacrifice of the animals to get enough volume.

\section{6 - Blood kinetic study}

Animal care was administered in strict accordance to French Ministry of Agriculture regulations. One hundred and fifty microlitres of fluorescent LNCs were injected in the tail vein of sixweek old female Swiss mice (20-22g) (Ets Janvier, Le Genest-St-ile, France). The fluorescence was 
measured at Time 1, 5, 15, 30,60, 120, 240, 300min. and 24h. At each time, blood sampling was performed by cardiac puncture on 3 mice and each sample was centrifuged for $10 \mathrm{~min}$ at $2,000 \mathrm{~g}$ in a venous blood collection tube (Vacutainer, SST II Advance, 5 ml, Becton Dickinson France SAS, Le Pont-De-Claix, France). One hundred and fifty microlitres of the supernatant were deposited in a black, 96-well plate (Greiner Bio-one, Frickenhausen, Germany). Empty samples were constituted by the supernatant of centrifuged blood taken from 3 mice injected with an isotonic solution $(150 \mathrm{mM}$ $\mathrm{NaCl}$ ), representing the residual fluorescence of the plasma. Dil fluorescence (ex: $544 \mathrm{~nm}$, em: 590 nm) was counted by a Fluoroscan (Ascent FL, Thermo Fisher Scientific, Cergy-Pontoise, France) and the results were analyzed with the Ascent software for Fluoroscan (Thermo Fisher Scientific, CergyPontoise, France). The blood concentration of the different particles at the various times was calculated on the assumption that blood represents $7.5 \%$ of mouse body weight [17]. Fluorescence was expressed in fluorescence units (FU) and was calculated as: FUsample - FUempty. $100 \%$ of fluorescence was considered as the value at $t=1 \mathrm{~min}$.

Pharmacokinetic data were treated by non-compartmental analysis of the percentage of the injected dose versus time profiles with Kinetica 4.1.1 software (Thermo Fisher Scientific, Villebon sur Yvette, France). The half-lives were calculated as following: $t_{1 / 2}=\log (2) / L z$. The $L z$ was determined from linear regression using defined intervals (5h and $24 \mathrm{~h}$ for $t_{1 / 2}$ distribution [0-5h] and $t_{1 / 2}$ elimination [0-24h] respectively). The trapezoidal rule was used to calculate the area under the curve (AUC) during the whole experimental period (AUC [0-24h]) without extrapolation, as well as the area under the first moment curve (AUMC). The mean residence time was calculated from 0 to $5 \mathrm{~h}$, from the following equation: MRT [0-5h] = AUMC [0-5h] / AUC [0-5h].

\section{7 - In vivo fluorescence imaging}

Tumor bearing mice were prepared by injecting subcutaneously a suspension of $1 \times 10^{6}$ U87MG glioma cell line (ATCC, Manassas, VA) in 150 $\mu$ l of Hanks Balanced Saline Solution (HBSS) into the right flank of athymic nude mice (6 weeks old females, $20-24 \mathrm{~g}$, purchased from Charles Rivers, Wilmington, Ma). In order to evaluate the biodistribution of coated DNA LNCs and uncoated DNA LNCs in tumor bearing mice, LNCs were labeled with DiD, a near-infrared (NIR) fluorophore. 
After 21 days, $150 \mu \mathrm{l}$ of nanoparticles were injected via the tail vein of the mice presenting tumors on their right flank. Non invasive fluorescent imaging was then performed $3 \mathrm{~h}, 5 \mathrm{~h}, 24 \mathrm{~h}$ and $48 \mathrm{~h}$ postinjection using the biofluorescence imaging (BFI) system of the LB 983 NightOWL II (Berthold France - Thoiry - France) equipped with cooled slow scan CCD camera and driven with the WINLIGHT software. (Berthold France, Thoiry, France). As DiD fluorescent tag was used to localize the nanoparticles, the $590 \mathrm{~nm}$ excitation filter and the $655 \mathrm{~nm}$ emission filter were selected. In parallel, the light beam was kept constant for each fluorescent measurement, which was ideal with the ringlight epi illumination. If the ringlight was always set at the same height, the excitation energy on the sample would always be the same.

Each mouse was anesthetized with a $4 \%$ air-isofluran blend. Once laid in the acquisition chamber, the anesthesia of the mice was maintained with a $2 \%$ air-isofluran mixture all along the experiment. With the BFI system, the fluorescent acquisition time was $2 \mathrm{sec}$ and the fluorescent signal was then overlaid on a picture of the mice.

CCD camera collected light coming out from the skin of the animal without any a priori information regarding the deepness of the sources. However, excitation and emission photons employed in our experiments have a mean path before absorption of 1-2 cm, and this property depends on the optical characteristic of tissues themselves. Thus, since the photons can pass up to 2 $\mathrm{cm}$ through the animal body, sources located up to $2 \mathrm{~cm}$ below the skin can be visualized. However, in order to unambiguously localize the fluorescent dye accumulated in specific anatomical areas, a much more detailed study should be performed. 


\section{3 - Results}

\section{1 - Preparation of stealth DNA LNCs and physicochemical characterization of the different coatings}

The physico-chemical properties (Table 1) and the DNA encapsulation ability (Figure 1) of DNA LNCs were examined before and after the post-insertion of DSPE-mPEG 2000 or F108. We used DSPE-mPEG $\mathrm{m}_{2000}$ concentrations from 2 to $10 \mathrm{mM}$, and $\mathrm{F} 108$ concentrations from 1 to $3 \mathrm{mM}$. The high molecular weight of F108 $(14,600 \mathrm{Da})$ did not allow us to associate more than $3 \mathrm{mM}$ of $\mathrm{F} 108$ at the LNC surface. Above this concentration demixing was observed, indicating an excess of F108. A higher density of DSPE-mPEG 2000 chains was therefore possible to obtain at the LNC surface.

Compared to empty LNCs (48 $\pm 4 \mathrm{~nm}$ ), the lipoplexe-loaded LNCs (DNA LNCs) demonstrated a significant increase in size $(117 \pm 10 \mathrm{~nm})$ and zeta potential measured in a final concentration of 1,5 $\mathrm{mM} \mathrm{NaCl}(+30 \pm 2 \mathrm{mV}$ versus $-14 \pm 1 \mathrm{mV}$ for empty LNCs) (Table 1$)$. The mean size obtained after the post-insertion of DSPE-mPEG 2000 was $131 \pm 10,139 \pm 19$ and $142 \pm 20 \mathrm{~nm}$ for $2,5,10 \mathrm{mM}$ respectively. When adding F108 block copolymers, the sizes were weakly increased with $129 \pm 2,129$ \pm 4 , and $132 \pm 3$ for $1,2,3 \mathrm{mM}$ respectively. In all cases, size increase was between 130 and $142 \mathrm{~nm}$, whatever the concentration, without significant differences. The zeta potential values decreased progressively from $+30 \mathrm{mV}$ for DNA LNCs to $-41 \mathrm{mV}$ with increasing concentrations of DSPE$\mathrm{mPEG}_{2000}$. DNA LNC zeta potentials decreased more weakly in the case of F108 incorporation, i.e. $+14,+17$ and $+22 \mathrm{mV}$ for 1,2 and $3 \mathrm{mM}$, respectively.

Agarose gel electrophoresis experiments showed that DNA molecules did not migrate after the nanocapsule formulation process. By contrast, incubation of nanocapsules with $\operatorname{Triton}^{\circledR}$ led to the release of DNA molecules that migrated into the gel (Figure 1). These results clearly indicate that the addition of polymers at the surface of DNA LNCs does not disturb encapsulation (lanes 4 to 15) and that DNA molecules remain well encapsulated inside nanoparticles.

\section{2 - Macrophage uptake}


Free lipoplexes, empty LNCs or encapsulated lipoplexes (DNA LNCs) were firstly tested for their cytotoxicity against THP-1 cells (Figure 2). Free DNA was clearly non-toxic to THP-1 cells whatever the concentration from 0.46 to $44.6 \mu \mathrm{g} / \mathrm{ml}$. Empty LNCs and DNA LNCs were not toxic at concentrations under $4.46 \mu \mathrm{g} / \mathrm{ml}$. By contrast, at this concentration, free lipoplexes induced significant cell death (45\% of cell survival versus $100 \%$ for LNCs encapsulating the same DNA concentration). The encapsulation of lipoplexes in LNCs thus provided an efficient loss of toxicity.

The influence of PEG concentration and chain length in empty and DNA-LNCs on macrophage uptake was then studied. For this purpose, fluorescent LNCs were synthesized allowing the tracking of these vectors inside macrophage cells (THP-1 lineage) by fluorescent confocal microscopy (Figure 3A). DNA LNCs were loaded with both Dil fluorochrome (associated to the lipid core) and lipoplexes. The cells were treated with a dose of $1.5 \mathrm{mg} / \mathrm{ml}$ of nanocapsules (representing 4.46 $\mu \mathrm{g}$ of DNA per ml). DNA LNCs and 2mM F108-coated DNA LNCs were internalised within 20 minutes at $37^{\circ} \mathrm{C}$, mostly inside vesicles. Empty LNCs and 5mM DSPE-mPEG 2000 -coated DNA LNCs did not give any signal within the cells, suggesting the absence of particle uptake. This was confirmed by quantitative analysis exposing the number of dots per cell (Figure 3B) and showing that DSPE$\mathrm{mPEG}_{2000}$-coated DNA LNCs have the same behavior as empty LNCs. Same data were obtained after 24 hours of incubation at $37^{\circ} \mathrm{C}$ (data not shown).

\section{3 - Complement consumption}

Complement consumption was evaluated as the lytic capacity of the serum towards $50 \%$ of antibody-sensitized sheep erythrocytes ( $\mathrm{CH} 50$ units) after exposure to free lipoplexes, empty LNCs, DNA LNCs and DNA LNCs coated with different concentrations of DSPE-mPEG ${ }_{2000}$ (Figure 4A) and F108 (Figure 4B).

PMMA nanoparticles, already described as strong complement activators [14], exposed a $\mathrm{CH} 50$ consumption of $100 \%$ at low concentrations (expressed in nanoparticle surface area). Free lipoplexes, which are positively charged, were even stronger activators than PMMA particles, with $100 \%$ of $\mathrm{CH} 50$ unit consumption for a lower concentration. The consumption of $\mathrm{CH} 50$ units reached a maximum of $5 \%$ for empty LNCs, whereas DNA LNCs led to $25 \%$ of consumption with the same quantity of 
nanoparticles. Nevertheless, for the same DNA concentration, the consumption unit of free lipoplexes was much stronger than lipoplexes encapsulated in LNCs (DNA LNCs). When coated with DSPE$\mathrm{mPEG}_{2000}$, DNA LNCs were weaker activators than non-covered DNA LNCs (Figure 4A), because less than $10 \%$ of $\mathrm{CH} 50$ unit consumption was obtained, whatever the quantity of particles and the polymer concentration (2, 5 and 10mM). In the case of F108 (Figure 4B), complement activation obtained with this coating reached $20 \%$ of $\mathrm{CH} 50$ unit consumption for 1 and $2 \mathrm{mM}$. The nanocapsules coated with F108 at a concentration of 3mM showed an even higher activation level than non-coated DNA LNCs.

\section{5 - Blood distribution of LNCs in Swiss mice}

With the goal of following the blood half-lives of LNCs in Swiss mice, we used fluorescentlabeled LNCs injected in the tail vein at a DNA concentration of $3.35 \mathrm{mg} / \mathrm{kg}$ of animal weight. Thereafter blood samples were collected from one minute (expressed as the $100 \%$ of the injected dose) to 24 hours, and the plasma was dosed for its fluorescent content.

In parallel, blood samples were harvested for the dosage of transaminases ALAT (alanine amino transferase) and ASAT (aspartate aminotransferase) (data not shown). In comparison of these mice before administration of the LNCs $($ ALAT $=40.83 \pm 30.88$; ASAT $=23.04 \pm 5.45)$, an increase of these two enzymes in the plasma $24 \mathrm{~h}$ after the injection of non coated DNA LNCs (ALAT $=410.18 \mathrm{UI} / \mathrm{l}$, ASAT $=507.41 \mathrm{UI} / \mathrm{l})$ was noted whereas no or lowest increase was detected for F108 (ALAT $=$ 62.90UI/I, ASAT $=69.90 \mathrm{UI} / \mathrm{l})$ and DSPE-mPEG $2000^{-}$coated DNA LNCs $($ALAT $=193.18 \mathrm{UI} / \mathrm{I}$, ASAT $=$ 208.67UI/I) respectively.

As seen in Figure 5, DNA LNCs were quite rapidly cleared from the circulation with $50 \%$ of fluorescence detected in the plasma at $0.3 \mathrm{~h}$ post injection (versus $0.7 \mathrm{~h}$ for empty LNCs). DNA LNCs coated with $2 \mathrm{mM}$ DSPE-mPEG ${ }_{2000}$ exhibited a $\mathrm{t}_{1 / 2}$ of distribution increase from 1.4h to $1.6 \mathrm{~h}$ (Table 2), and the AUC raised from 194 to $325 \%$ of the injected dose per hour (Table 2). When adding $5 \mathrm{mM}$ and $10 \mathrm{mM}$ of DSPE-mPEG 2000 , respectively, to the surface of DNA LNCs, $47 \%$ and $56 \%$ of the injected dose was still circulating 4 hours after injection (Figure $5 \mathrm{~A}$ ), to reach a $t_{1 / 2}$ of distribution of 7.1 hours with $10 \mathrm{mM}$ of DSPE-mPEG 2000 . The AUCs of these formulations were 539 and $773 \%$ of the injected dose per hour respectively (Table 2), which represents a huge increase compared to DNA LNCs 
(194\%). The mean residence time (MRT) was of $2.3 \mathrm{~h}$ and $2.4 \mathrm{~h}$ for DNA LNCs coated with DSPE PEG $5 \mathrm{mM}$ and $10 \mathrm{mM}$ (versus $1.5 \mathrm{~h}$ for DNA LNCs) and the $\mathrm{t}_{1 / 2}$ of elimination reached 8.6 hours with DSPEPEG 10mM (versus 5.5h with DNA LNCs).

When adding 1,2 and $3 \mathrm{mM}$ of $\mathrm{F} 108$, the $\mathrm{t}_{1 / 2}$ of distribution were of $1.7,1.9$ and $2.7 \mathrm{~h}$, respectively. The $t_{1 / 2}$ of elimination attained 7 hours whatever the concentration of F108 at the LNC surface. Although the coating of DNA LNCs with F108 showed a weak improvement in $t_{1 / 2}$ of distribution, the AUC [1-24h] was increased (with 366, 355, and $453 \%$ of the injected dose per hour, for 1,2 and $3 \mathrm{mM}$, respectively). The MRT reached $2 \mathrm{~h}$ with these block copolymers at the surface of DNA LNCs.

\section{6 - Tumor accumulation of coated DNA LNCs}

To estimate time dependant excretion profile and tumor accumulation of the polymer coated LNCs exposing the greatest residence time in blood stream (10mM DSPE-mPEG ${ }_{2000}$ ), these suspensions were intravenously injected in the tail vein of tumor bearing mice and compared to non coated DNA LNCs. Tissue distribution was evaluated thanks to NIR biofluorescence imaging (BFI) system. First of all, the early fluorescence signals were much more intense after injection of coated DNA LNCs than after the administration of uncoated particles. When regarding non covered DNA LNCs, the fluorescence intensity increased in the liver area from $3 \mathrm{~h}$ after injection up to $24 \mathrm{~h}$, whereas

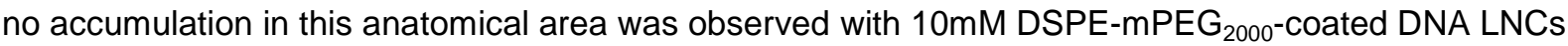
at any time (Figure 6). In parallel, a fluorescence emission was observed $3 \mathrm{~h}, 5 \mathrm{~h}, 24 \mathrm{~h}$, and $48 \mathrm{~h}$ after DNA LNCs injection on the kidney area, which could therefore let think to an elimination of DNA LNCs via urinary system. At $24 \mathrm{~h}$ and $48 \mathrm{~h}$ after injection, DSPE-mPEG ${ }_{2000}-$ covered DNA LNCs displayed stronger fluorescence intensity in the tumor and in its vicinity, compared to non coated DNA LNCs. 


\section{4 - Discussion}

The formulation process led to the creation of empty LNCs or DNA LNCs with very different size and surface charge properties (Table 1) predicting a difference of behavior when confronted with a biological environment. By coating DNA LNCs with amphiphilic polymers, our aim was to improve their circulation time in order to give them the adequate features for in vivo injection and tumor accumulation.

PEG lipid derivatives DSPE-mPEG 2000 and block copolymers F108 were associated to preformed nanocapsules by the post-insertion method, usually used to create stealth liposomes, and recently applied to LNCs $[18,19]$. The centrifugation $\left(15,000 \mathrm{~g}, 20 \mathrm{~min} ., 20^{\circ} \mathrm{C}\right)$ of coated DNA LNCs revealed a good level of stability of all the particles. Nevertheless, high concentrations of F108 (>3mM) led to demixing (data not shown), whereas this was never observed with DSPE-mPEG 2000 at any concentration. This could be explained by steric overcrowding, due to the high molecular weight of F108 chains $(14,600 \mathrm{Da})$ that induced a weaker reachable density of F108 molecules at the surface of the particles (Table 3). The theoretical calculations of several characteristics of the coating exposed in Table 3 were based on the mean diameter measurements $\left(A=4 \pi r^{2}\right)$, the molar concentration of the post-inserted polymers at the surface of DNA LNCs and on the assumption that there was a full binding of the polymers $[20,21]$.

Agarose gel electrophoresis experiments showed no migration of DNA molecules after nanocapsule formulation followed by post-insertion, indicating that (a) coated DNA LNCs were stable, (b) most of the lipoplexes were encapsulated, and (c) DNA molecules were not degraded by the coating process. Cytotoxicity studies confirmed the biocompatibility of empty LNCs and DNA LNCs compared to free lipoplexes (Figure 2) This is a significant advantage of DNA LNCs when confronting lipoplexes, certainly due to charge dissimulation [1].

As already described [5, 6, 14], free lipoplexes and PMMA NP strongly activated the proteins of the complement system as assessed in vitro by the $\mathrm{CH} 50$ test (Figure 4). The high cationic and anionic charges at lipoplexe and PMMA NP surfaces respectively, govern interactions with plasmacomplement proteins via the alternative pathway and also interactions with cells membranes [22, 23]. In comparison with empty LNCs that present no complement activation and no macrophage uptake 
(Figures 3 and 4), DNA LNCs showed weak complement activity, but more pronounced macrophage uptake (Figure 4). While the coating of DNA LNCs with F108 led to the same activation as with noncoated DNA LNCs, DSPE-mPEG 2000 led to the inhibition of complement activation down to the empty LNC level. As expected, the addition of DSPE-mPEG 2000 improved macrophage escape (Figure 3). The high charge of DNA LNCs $(+30 \mathrm{mV})$ was dissimulated thanks to the use of DSPE-mPEG ${ }_{2000}$ polymers, to reach a still positive $(+22 \mathrm{mV})$ or negative $(-12 \mathrm{mV}$ or $-41 \mathrm{mV})$ surface charge. These differences of zeta potentials are linked to the fact that DSPE-PEG chains can form negative dipoles that are able to diminish the surface charge proportionally to their concentration [24]. This negative charge, close to that of empty LNCs $(-14 \mathrm{mV})$ prevented their removal via non-specific interactions with receptors by electrostatic attraction at the macrophage surface $[25,26]$, mainly observed with positive charges. By contrast, F108-coated DNA LNCs were largely taken up; this could be linked to their positive charge $(+22 \mathrm{mV})$ or to a dissociation of F108 copolymers and DNA LNCs which resulted in their rapid uptake by the MPS. One hypothesis is also that the PPO hydrophobic moieties present on F108 could be accessible to opsonins and consequently provide more association to cells compared to the hydrophobic moieties of DSPE-mPEG ${ }_{2000}$ which are anchored in the nanocapsule core $[18,27]$. It is now well established that a dissociation of the PEG chains from the particles is required to interact with cell membranes [28] and, in this case, the disadvantage of F108 can become an advantage. Indeed, DSPE-mPEG ${ }_{2000}$ coated DNA LNCs were less efficient than F108 covered ones in in vitro HeLa cell transfection as previously described [29]. Anyway, there is, in vivo, a need of finding equilibrium between transfection and pharmacokinetic behavior [28].

As our final aim was to obtain long-circulating vectors for systemic gene delivery, we then investigated the plasma clearance of fluorescent LNCs in Swiss mice. It is well known that the low circulation time of free lipoplexes explains their poor efficiency for gene delivery in vivo, with only $1 \%$ detected in the blood 5 min after injection in mice [30]. By contrast, DNA LNCs exposed $93 \%$ of the injected dose at the same time (Figure 5).

In order to enhance their circulation time we chose to protect the DNA LNC surface with DSPE-mPEG 2000 or $\mathrm{F} 108$ poloxamers. The half-lives and the mean residence time for all the DSPEmPEG $_{2000}$ and F108-coated DNA LNCs were higher than for DNA LNCs However, F108 poloxamers did not efficiently improve circulation properties, probably because the surfactant is displaced on 
dilution in the blood and enters into competition with opsonins. This confirm that the anchorage of PEG chains in DNA LNCs is essential for prolonging the in vivo residence time [31]. By contrast, DSPEmPEG ${ }_{2000}$-coated DNA LNCs had extended half lives, and the blood circulation time increased with the density of DSPE-mPEG 2000 chains. The distance between two PEG chains from 5 to $2.33 \mathrm{~nm}$ (Table 3) and their density is in good agreement with other long-circulating systems such as PLA-PEG nanocapsules [31].

The excretion profile of DNA LNCs and 10mM DSPE-mPEG ${ }_{2000}$ DNA LNCs in live tumor bearing mice was then tested by monitoring real time NIR fluorescence intensity in the whole body, as this last formulation was the more promising in terms of circulation time. Near-infrared (NIR)-absorbing dyes represent an intriguing way for extracting biological information form living subjects since they can be monitored with safe, non-invasive optical imaging/contrasting techniques. While light in the visible range is routinely used for microscopy, imaging deeper tissues $(>500 \mu \mathrm{m}$ to $\mathrm{cm}$ ) required the used of near-infrared light, as hemoglobin and water, the major absorbers of visible and infrared light have their lowest coefficient in the NIR section $(650-900 \mathrm{~nm})$. The advantages of imaging in the NIR region are numerous: the significant reduction of background absorption, fluorescence and light scattering along with high sensitivity, the availability of low-cost sources of excitation and the versatility of different reporter probes.

Consistently with blood kinetic profiles (Figure 5 and Table 2), DNA LNCs were rapidly localized in the liver and in the kidney suggesting a removal by the MPS. By contrast, DSPE-mPEG ${ }_{2000}$ coated DNA LNCs were able to accumulate in the tumor and its neighborhood by passive targeting thanks to a sufficient circulation time in blood. The low hepatotoxic impact of these coated particles was also a positive point.

This newly formed vector can advantageously be compared to other gene therapy systems reported in the literature. Actually, as exposed in the study of Cui et al., 30 min. after tail-vein injection in mice, only $40 \%$ of the pDNA entrapped in nanoparticles synthesized from emulsion remained in the circulating blood [32]. Even the clinically relevant systemic RNAi-mediated gene silencing in nonhuman primates developed by Zimmermann et al. [33], exposed a half-life in mice of 38 minutes. However, the circulation time of stabilized plasmid lipid particles (SPLP) in the blood can vary from $1 \mathrm{~h}$ to $16 \mathrm{~h}$, depending on the PEG lipid anchor used. Nevertheless this study also showed that the PEG lipid anchor has to be disassociated from the particle surface in order to transform the complex from a 
stable particle to a transfection-competent entity [34-36], which occurs with one of the shortest lipid anchors $\left(\mathrm{C}_{14}\right)$ and a distribution $\mathrm{t}_{1 / 2}$ of $2 \mathrm{~h}$.

\section{5 - Conclusion}

The DSPE-mPEG 2000 coated DNA LNCs developed here are able to circulate in the bloodstream without being degraded or captured by the cellular defense mechanisms, and to accumulate in the tumor area. One hurdle, the extracellular one, is therefore crossed, but numerous barriers still exists at the cellular level, and efforts have to be made to still improve this vector. Nevertheless, this DNA delivery system seem to be an excellent candidate for an efficient in vivo transfection, either by the enhanced and permeability retention effect (EPR effect) [7] or by active targeting thanks to the grafting of specific molecules to the extremity of the longest PEG chains.

\section{Acknowledgments}

This research was supported by the Biogeneouest ${ }^{\circledR}$, the "SynNanoVect" IBiSA platform - Brest, INRA UMR 118, 35653 Le Rheu, France. 


\section{References}

1. Morille M, Passirani C, Vonarbourg A, Clavreul A, Benoit JP. Progress in developing cationic vectors for non-viral systemic gene therapy against cancer. Biomaterials 2008;29(24-25):3477-3496. 2. Kazatchkine MD, Carreno MP. Activation of the complement system at the interface between blood and artificial surfaces. Biomaterials 1988;9(1):30-35.

3. Vonarbourg A, Passirani C, Saulnier P, Benoit JP. Parameters influencing the stealthiness of colloidal drug delivery systems. Biomaterials 2006;27(24):4356-4373.

4. Heurtault B, Saulnier P, Pech B, Proust JE, Benoit JP. A novel phase inversion-based process for the preparation of lipid nanocarriers. Pharm Res 2002;19(6):875-880.

5. Vonarbourg A, Passirani C, Saulnier P, Simard P, Leroux JC, Benoit JP. Evaluation of pegylated lipid nanocapsules versus complement system activation and macrophage uptake. $\mathrm{J}$ Biomed Mater Res A 2006;78(3):620-628.

6. Vonarbourg A, Passirani C, Desigaux L, Allard E, Saulnier P, Lambert O, et al. The encapsulation of DNA molecules within biomimetic lipid nanocapsules. Biomaterials 2009;30(18):3197-3204.

7. Maeda H, Wu J, Sawa T, Matsumura Y, Hori K. Tumor vascular permeability and the EPR effect in macromolecular therapeutics: a review. J Control Release 2000;65(1-2):271-284.

8. Nguyen HK, Lemieux P, Vinogradov SV, Gebhart CL, Guerin N, Paradis G, et al. Evaluation of polyether-polyethyleneimine graft copolymers as gene transfer agents. Gene Ther 2000;7(2):126-138. 9. Ochietti B, Guerin N, Vinogradov SV, St-Pierre Y, Lemieux P, Kabanov AV, et al. Altered organ accumulation of oligonucleotides using polyethyleneimine grafted with poly(ethylene oxide) or pluronic as carriers. J Drug Target 2002;10(2):113-121.

10. Pitard B, Pollard H, Agbulut O, Lambert O, Vilquin JT, Cherel Y, et al. A nonionic amphiphile agent promotes gene delivery in vivo to skeletal and cardiac muscles. Hum Gene Ther 2002;13(14):1767-1775.

11. Kabanov AV, Lemieux P, Vinogradov $S$, Alakhov V. Pluronic block copolymers: novel functional molecules for gene therapy. Adv Drug Deliv Rev 2002;54(2):223-233.

12. Heurtault B, Saulnier P, Pech B, Venier-Julienne MC, Proust JE, Phan-Tan-Luu R, et al. The influence of lipid nanocapsule composition on their size distribution. Eur J Pharm Sci 2003;18(1):5561.

13. Garcion E, Lamprecht A, Heurtault B, Paillard A, Aubert-Pouessel A, Denizot B, et al. A new generation of anticancer, drug-loaded, colloidal vectors reverses multidrug resistance in glioma and reduces tumor progression in rats. Mol Cancer Ther 2006;5(7):1710-1722.

14. Passirani C, Barratt G, Devissaguet JP, Labarre D. Interactions of nanoparticles bearing heparin or dextran covalently bound to poly(methyl methacrylate) with the complement system. Life Sci 1998;62(8):775-785. 
15. Tsuchiya S, Kobayashi Y, Goto Y, Okumura H, Nakae S, Konno T, et al. Induction of maturation in cultured human monocytic leukemia cells by a phorbol diester. Cancer Res 1982;42(4):1530-1536.

16. Mosmann T. Rapid colorimetric assay for cellular growth and survival: application to proliferation and cytotoxicity assays. J Immunol Methods 1983;65(1-2):55-63.

17. Calvo P, Gouritin B, Chacun H, Desmaele D, D'Angelo J, Noel JP, et al. Long-circulating PEGylated polycyanoacrylate nanoparticles as new drug carrier for brain delivery. Pharm Res 2001;18(8):1157-1166.

18. Hoarau D, Delmas P, David S, Roux E, Leroux JC. Novel long-circulating lipid nanocapsules. Pharm Res 2004;21(10):1783-1789.

19. Beduneau A, Saulnier P, Hindre F, Clavreul A, Leroux JC, Benoit JP. Design of targeted lipid nanocapsules by conjugation of whole antibodies and antibody Fab' fragments. Biomaterials 2007;28(33):4978-4990.

20. Vittaz M, Bazile D, Spenlehauer G, Verrecchia T, Veillard M, Puisieux F, et al. Effect of PEO surface density on long-circulating PLA-PEO nanoparticles which are very low complement activators. Biomaterials 1996;17(16):1575-1581.

21. Lacoeuille F, Hindre F, Moal F, Roux J, Passirani C, Couturier O, et al. In vivo evaluation of lipid nanocapsules as a promising colloidal carrier for paclitaxel. Int J Pharm 2007;344(1-2):143-149.

22. Plank C, Mechtler K, Szoka FC, Jr., Wagner E. Activation of the complement system by synthetic DNA complexes: a potential barrier for intravenous gene delivery. Hum Gene Ther 1996;7(12):1437-1446.

23. Devine DV, Wong K, Serrano K, Chonn A, Cullis PR. Liposome-complement interactions in rat serum: implications for liposome survival studies. Biochim Biophys Acta 1994;1191(1):43-51.

24. Vonarbourg A, Saulnier P, Passirani C, Benoit JP. Electrokinetic properties of noncharged lipid nanocapsules: influence of the dipolar distribution at the interface. Electrophoresis 2005;26(11):20662075.

25. Hsu MJ, Juliano RL. Interactions of liposomes with the reticuloendothelial system. II: Nonspecific and receptor-mediated uptake of liposomes by mouse peritoneal macrophages. Biochim Biophys Acta 1982;720(4):411-419.

26. Gref R, Minamitake Y, Peracchia MT, Trubetskoy V, Torchilin V, Langer R. Biodegradable long-circulating polymeric nanospheres. Science 1994;263(5153):1600-1603.

27. Uster PS, Allen TM, Daniel BE, Mendez CJ, Newman MS, Zhu GZ. Insertion of poly(ethylene glycol) derivatized phospholipid into pre-formed liposomes results in prolonged in vivo circulation time. FEBS Lett 1996;386(2-3):243-246.

28. Ambegia E, Ansell S, Cullis P, Heyes J, Palmer L, MacLachlan I. Stabilized plasmid-lipid particles containing PEG-diacylglycerols exhibit extended circulation lifetimes and tumor selective gene expression. Biochim Biophys Acta 2005;1669(2):155-163.

29. Morille M, Passirani C, Letrou-Bonneval E, Benoit JP, Pitard B. Galactosylated DNA lipid nanocapsules for efficient hepatocyte targeting. Int J Pharm 2009. 
30. Zelphati O, Uyechi LS, Barron LG, Szoka FC, Jr. Effect of serum components on the physicochemical properties of cationic lipid/oligonucleotide complexes and on their interactions with cells. Biochim Biophys Acta 1998;1390(2):119-133.

31. Mosqueira VC, Legrand P, Gulik A, Bourdon O, Gref R, Labarre D, et al. Relationship between complement activation, cellular uptake and surface physicochemical aspects of novel PEG-modified nanocapsules. Biomaterials 2001;22(22):2967-2979.

32. Cui Z, Mumper RJ. Plasmid DNA-entrapped nanoparticles engineered from microemulsion precursors: in vitro and in vivo evaluation. Bioconjug Chem 2002;13(6):1319-1327.

33. Zimmermann TS, Lee AC, Akinc A, Bramlage B, Bumcrot D, Fedoruk MN, et al. RNAimediated gene silencing in non-human primates. Nature 2006;441(7089):111-114.

34. Zhang YP, Sekirov L, Saravolac EG, Wheeler JJ, Tardi P, Clow K, et al. Stabilized plasmidlipid particles for regional gene therapy: formulation and transfection properties. Gene Ther 1999;6(8):1438-1447.

35. Wheeler JJ, Palmer L, Ossanlou M, MacLachlan I, Graham RW, Zhang YP, et al. Stabilized plasmid-lipid particles: construction and characterization. Gene Ther 1999;6(2):271-281.

36. Mok KW, Lam AM, Cullis PR. Stabilized plasmid-lipid particles: factors influencing plasmid entrapment and transfection properties. Biochim Biophys Acta 1999;1419(2):137-150. 


\section{FIGURES}

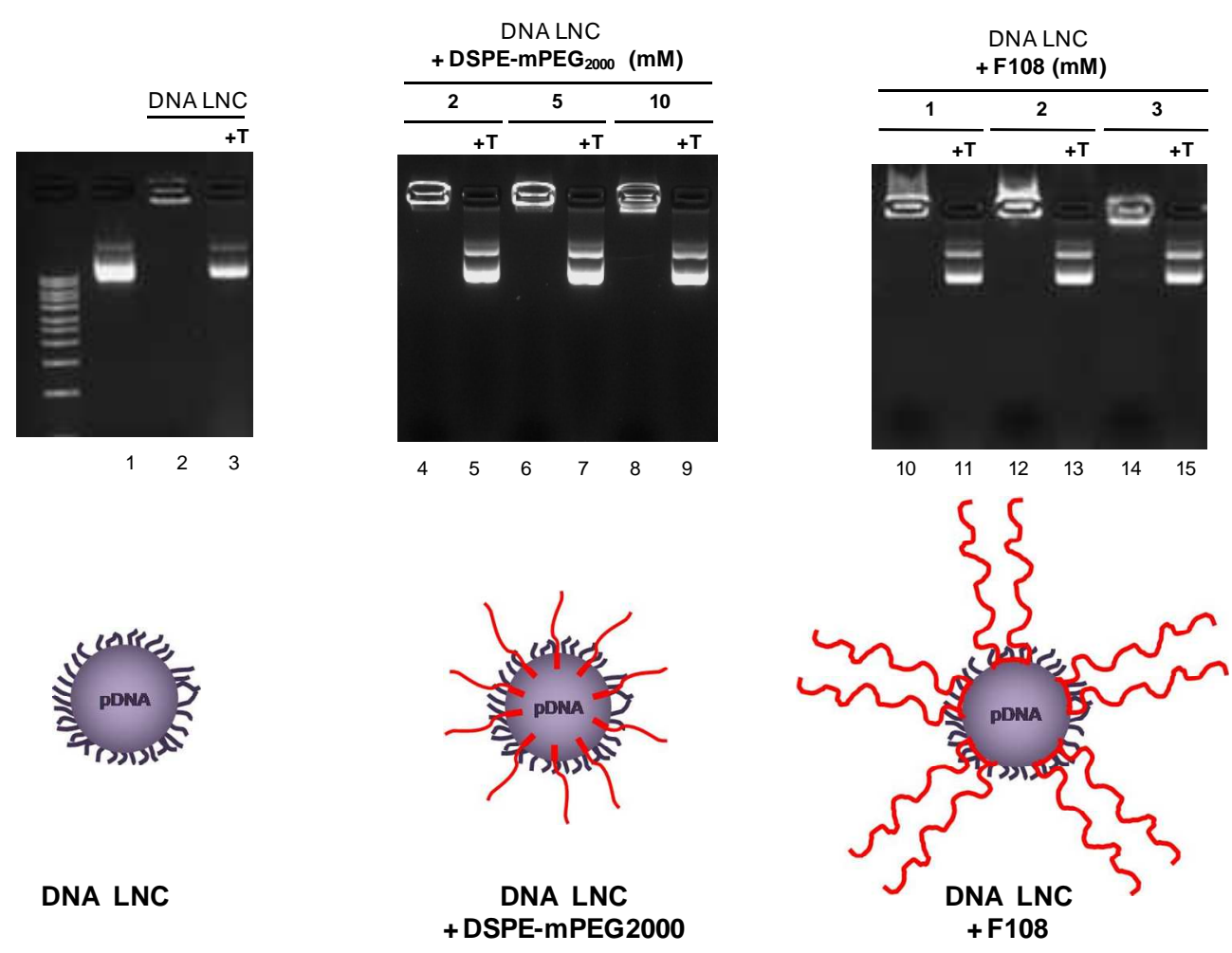

Figure 1. Encapsulation efficiency of DNA in LNCs and schematic representation of the different DNA

LNCs. The influence of coating on encapsulation efficiency was tested for all types of DNA LNC suspensions: DSPE-mPEG 2000 -coated (lanes 4 to 9) and F108-coated DNA LNCs (lanes 10 to 15). No migration of DNA into the gel indicates an efficient encapsulation. DNA molecules can not migrate once encapsulated in nanocapsules (lane 2), contrary to free DNA (pCMVluc) (lane1). The incubation of nanocapsules with $\operatorname{Triton}^{\circledR} \mathrm{X} 100(+\mathrm{T}$ ) led to the release of DNA molecules that migrated into the gel (lanes 3,5,7,9,11,13 and 15). 


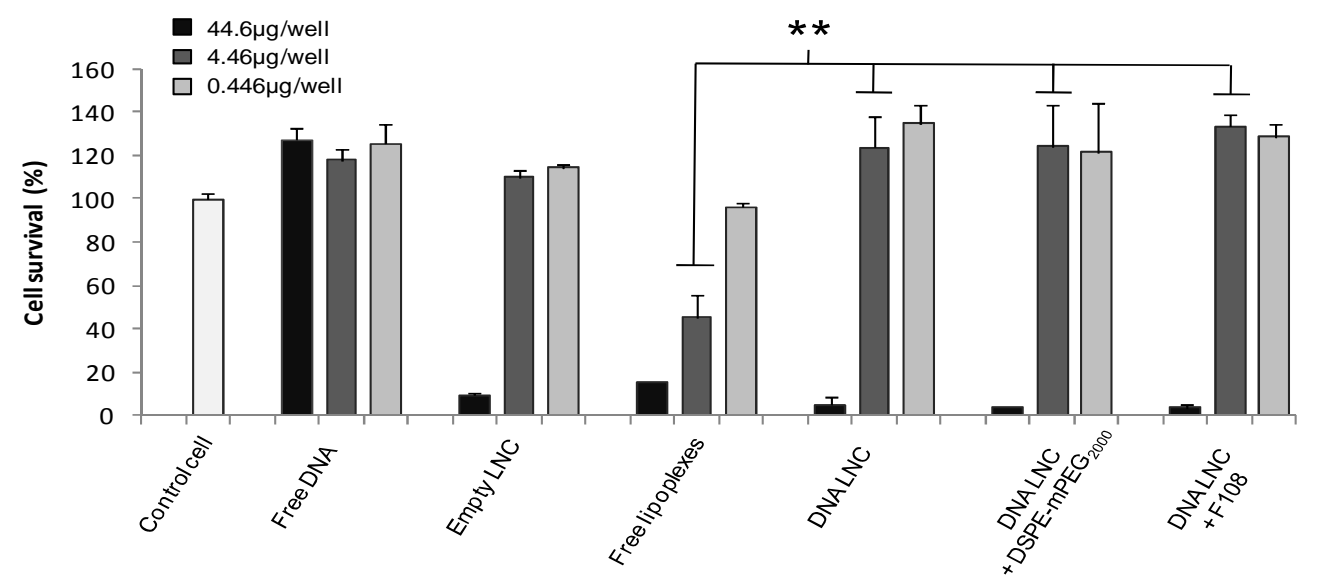

Figure 2. Particle cytotoxicity assessed by the MTT test. THP-1 cells were confronted with different formulations : free DNA, free lipoplexes, DNA LNCs, 5mM DSPE-mPEG 2000 and 2mM F108-coated DNA LNCs, at different concentrations of pDNA: $44.6 \mu \mathrm{g}, 4.46 \mu \mathrm{g}$, and $0.46 \mu \mathrm{g}$ per well. Cells without treatment were taken as the reference $(100 \%)$. As a control, empty LNCs were added at the same concentration (mg of LNC components per $\mathrm{ml}$ ) of DNA LNCs. Results are expressed as the percent of the optical density of the cells alone, as the mean \pm SD of 3 wells in 2 independent experiments. ${ }^{* *}: \mathrm{P}<0.01$ (Dunnett test). 
A.

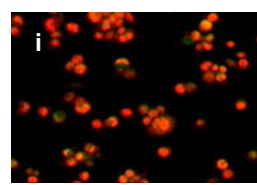

Empty LNC

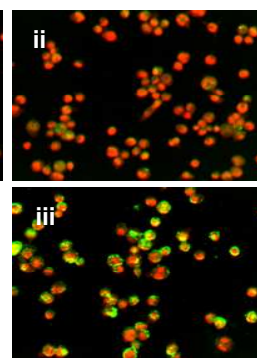

DNALNC
DNA LNC

+ DSPE-mPEG $20005 \mathrm{mM}$

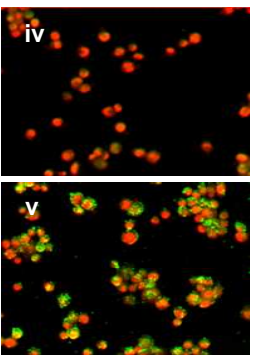

DNA LNC $+\mathrm{F} 1082 \mathrm{mM}$

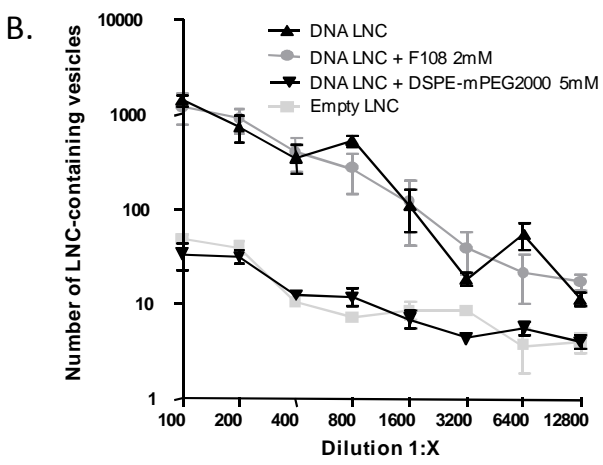

Figure 3. Quantitative fluorescent confocal microscopy of living THP-1 cells exposed to fluorescent Dillabelled blank LNCs (i), DNA LNCs(ii) and coated DNA LNCs with DSPE-mPEG 2000 (iv) and F108 (v). The different Dil-labelled suspensions were incubated with differentiated THP-1 macrophages for $20 \mathrm{~min}$ at $37^{\circ} \mathrm{C}$. After extensive washes, cells were labelled with Syto60 red stain and images were acquired using an automated, confocal, fluorescence microscope. Representative pictures are shown in panel A. Dil-labelled vesicles can be seen in green. Note the important internalisation observed with non-coated DNA LNCs (iii) and F108-coated DNA LNCs (iv) whereas really small amounts of DNA LNCs coated with DSPE-PEG $5 \mathrm{mM}$ are detected. Images span $0.450 \times 0.340 \mathrm{~mm}^{2}$. Image-based quantification of the number of LNC-containing vesicles is displayed for serial 2fold dilutions of each LNC type (panel B). 
A.

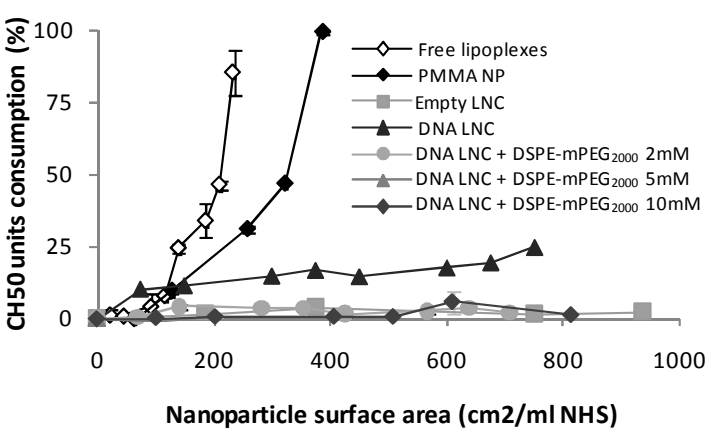

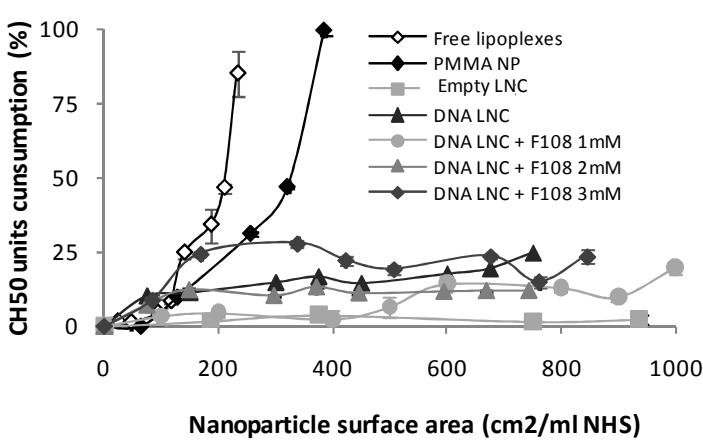

Figure 4. Influence of DSPE-mPEG 2000 (A) and F108 (B) on complement consumption by DNA LNCs. The $\mathrm{CH} 50$ consumption was represented as a function of the nanoparticle surface area $\left(\mathrm{cm}^{2}\right)$ representing an increase in nanocapsule concentration. Suspensions of nanoparticles were incubated for $60 \mathrm{~min}$ at $37^{\circ} \mathrm{C}$ in human se rum diluted $1 / 4(\mathrm{v} / \mathrm{v})$ in $\mathrm{VBS}^{2+}$. Complement consumption was evaluated as the lytic capacity of the serum (amount of CH50 units) towards antibody-sensitised sheep erythrocytes after exposure to blank LNCs, DNA LNCs and DNA LNCs coated with different concentrations of DSPE-mPEG $2000(A)$ and F108 (B). Each datum point represents the group mean \pm s.d. of the $\mathrm{CH} 50$ unit consumption. 
A.

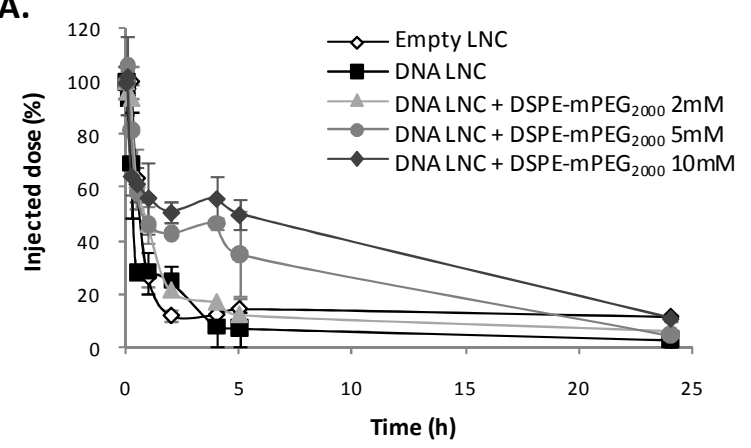

B.

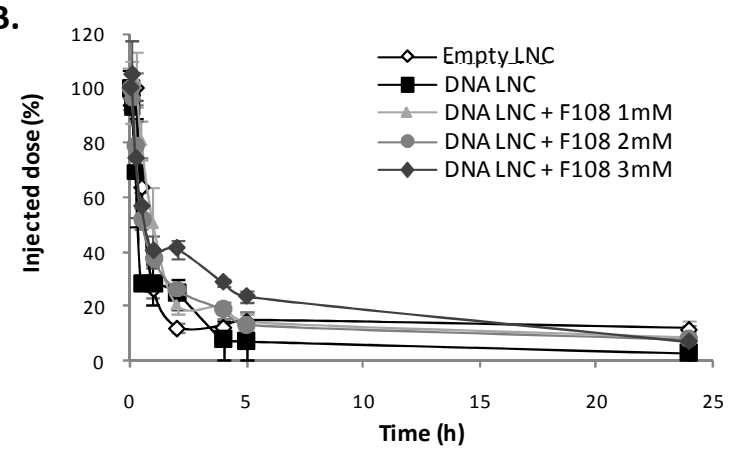

Figure 5. Kinetic blood profiles of LNCs coated with various concentrations of DSPE-mPEG 2000 (A) or F108

(B) following systemic injection in Swiss mice. The percentage of injected dose (3.35mg of DNA/kg of animal weight) remaining in plasma following a single bolus injection is displayed as a function of time. Administration of empty LNCs and DNA LNCs are shown as a control. Each datum point represents the group mean \pm s.d. of the percent injected dose. 
$3 h$

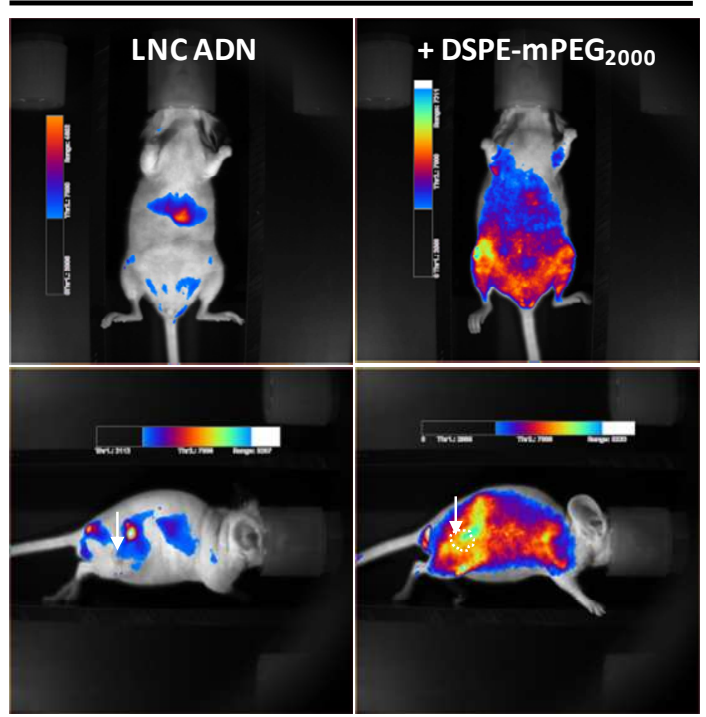

$24 \mathrm{~h}$

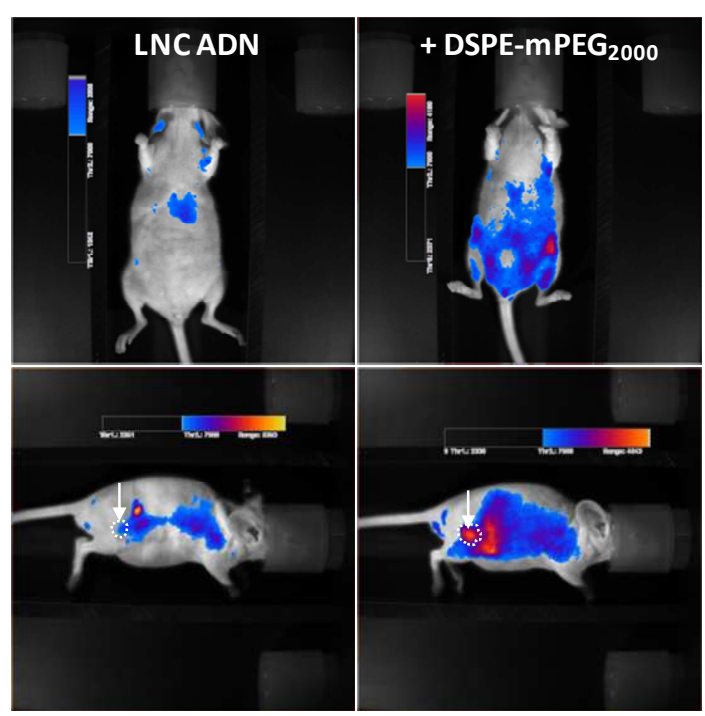

$5 \mathrm{~h}$

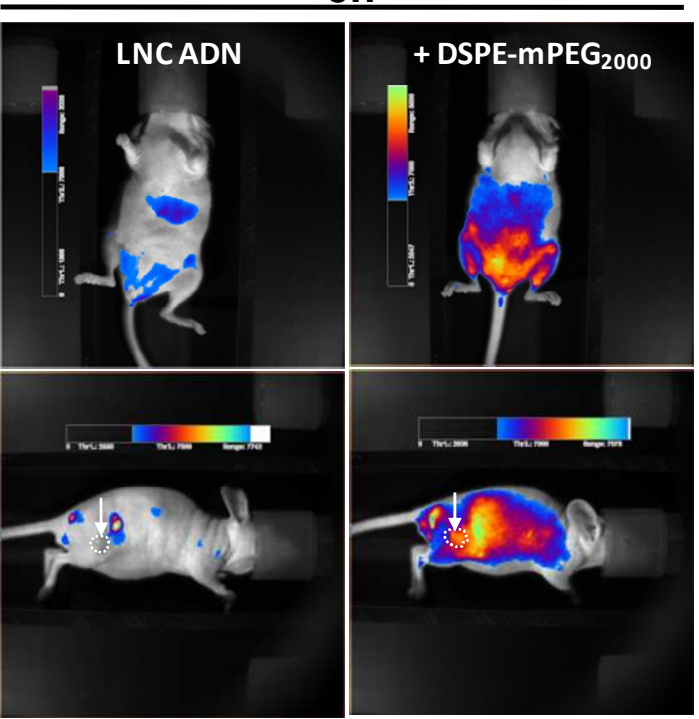

$48 h$

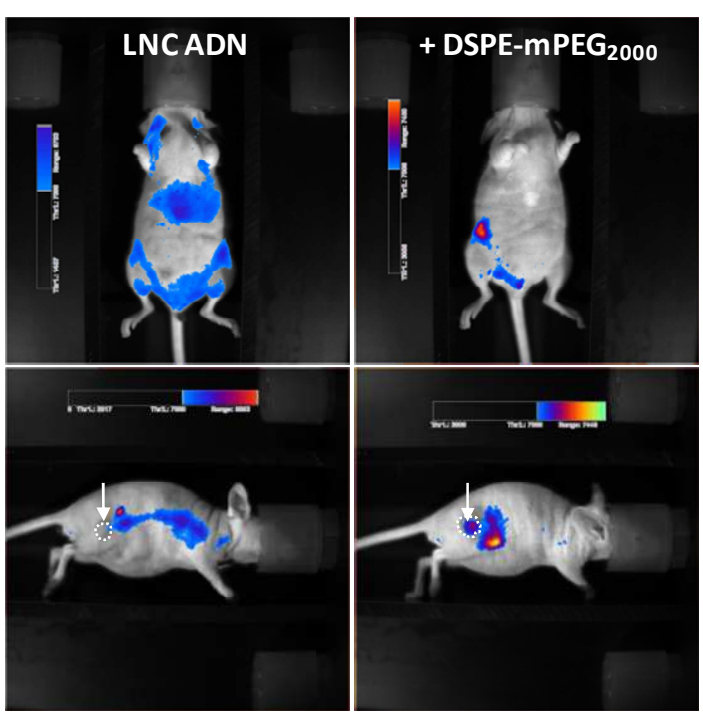

Figure. 6 In vivo fluorescence imaging of athymic nude mice bearing U87MG tumors after intravenous injection of DNA LNCs or DSPE-mPEG ${ }_{2000}$ coated DNA LNCs. Optical images of nude mice with $152 \mathrm{mg} / \mathrm{ml}$ tail vein injection of DNA LNCs or DSPE -mPEG 2000 coated DNA LNCs (representing $46 \mu$ of pDNA per mice). Coloured bar on the left or upper part of the picture indicates the signal efficient of the fluorescence emission coming out from the animal. The tumor location is specified with a white arrow. 


\section{TABLES}

\begin{tabular}{lccc} 
LNC formulation & Mean size $(\mathbf{n m})$ & Pdl & Zeta potential (mV) \\
\hline Empty LNC & $48 \pm 4$ & 0.020 & $-14 \pm 1$ \\
\hline DNA LNC & $117 \pm 10$ & 0.255 & $+30 \pm 2$ \\
\hline DNA LNC + DSPE-PEG 2000 2mM & $131 \pm 10$ & 0.230 & $+23 \pm 8$ \\
DNA LNC + DSPE-PEG 2000 5mM & $139 \pm 19$ & 0.374 & $-12 \pm 3$ \\
DNA LNC + DSPE-PEG 2000 10mM & $142 \pm 20$ & 0.250 & $-41 \pm 11$ \\
\hline DNA LNC + F108 1mM & $129 \pm 2$ & 0.209 & $+14 \pm 2$ \\
DNA LNC + F108 2mM & $129 \pm 4$ & 0.256 & $+17 \pm 3$ \\
DNA LNC + F108 3mM & $132 \pm 3$ & 0.248 & $+22 \pm 1$ \\
\hline
\end{tabular}

Table 1. Influence of the incorporation of DSPE-mPEG ${ }_{2000}$ and F108 at the surface of DNA LNCs on size, polydispersity and zeta potential. Results show the mean \pm SD of at least 4 independent formulation measurements and 3 measurements per sample. 


\begin{tabular}{|c|c|c|c|c|}
\hline Formulation & $\begin{array}{c}\mathrm{t}_{1 / 2} \text { distribution } \\
{[0-5 \mathrm{~h}]} \\
\text { (h) }\end{array}$ & $\begin{array}{c}\mathrm{t}_{1 / 2} \text { elimination } \\
{[0-24 \mathrm{~h}]} \\
\text { (h) }\end{array}$ & $\begin{array}{c}\text { MRT [0-5h] } \\
\text { (h) }\end{array}$ & $\begin{array}{c}\text { AUC [0-24h] } \\
\text { (\% injected dose/h) }\end{array}$ \\
\hline DNA LNC & $1.4 \pm 0.1$ & $5.5 \pm 0.3$ & $1.5 \pm 1.1$ & $194 \pm 3.2$ \\
\hline DSPE-PEG $2 \mathrm{mM}$ & $1.6 \pm 0.2$ & $7.1 \pm 1.8$ & $1.6 \pm 1.7$ & $325 \pm 5.4$ \\
\hline $\mathrm{F} 1081 \mathrm{mM}$ & $1.7 \pm 0.2$ & $7.5 \pm 0.4$ & $1.7 \pm 2.8$ & $366 \pm 6.1$ \\
\hline $\mathrm{F} 1082 \mathrm{mM}$ & $1.9 \pm 0.1$ & $7.6 \pm 1.1$ & $1.8 \pm 1.3$ & $355 \pm 5.9$ \\
\hline $\mathrm{F} 1083 \mathrm{mM}$ & $2.7 \pm 0.1$ & $7.0 \pm 0.9$ & $2.1 \pm 0.8$ & $453 \pm 7.5$ \\
\hline
\end{tabular}

Table 2. The main pharmacokinetic characteristics of various formulations of LNCs after a single i.v. injection in Swiss mice. Plasma clearance of LNCs was measured over a $24 \mathrm{~h}$ period in animals treated with $3.345 \mathrm{mg}$ of DNA $/ \mathrm{kg}$ of mouse weight. The half lives were calculated as follows: $t_{1 / 2}=\log (2) / L z$. The $L z$ was determined from linear regression using defined intervals (respectively $5 \mathrm{~h}$ and $24 \mathrm{~h}$, for $\mathrm{t}_{1 / 2}$ distribution [0-5h], and $t_{1 / 2}$ elimination [0-24h]). The AUC was calculated following the trapezoidal rule during the whole experimental period (1min to $24 \mathrm{~h}$ ) without extrapolation. The mean residence time was calculated from $1 \mathrm{~min}$ to $5 \mathrm{~h}$, from the following equation: MRT [0-5h] = AUMC [0-5h] / AUC [0-5h]. Each datum point represents the group mean \pm s.d. 


\begin{tabular}{|c|c|c|c|c|c|c|c|}
\hline & \multirow{2}{*}{$\begin{array}{c}\text { Non coated DNA LNC } \\
\text { Solutol }{ }^{\circledR *} \\
\text { PEG }_{660^{-}}-\mathrm{HS}\end{array}$} & \multicolumn{3}{|c|}{ DSPE-mPEG $2000(\mathrm{mM})$} & \multicolumn{3}{|c|}{$\mathrm{F} 108(\mathrm{mM})$} \\
\hline & & 2 & 5 & 10 & 1 & 2 & 3 \\
\hline $\begin{array}{l}\text { Number of molecules per } \\
\text { nanocapule }\end{array}$ & 14,046 & 1,297 & 3,254 & 6,509 & 648 & 1,297 & 1945 \\
\hline Surface density (molecules $/ \mathrm{nm}^{2}$ ) & 0.44 & 0.04 & 0.10 & 0.20 & 0.02 & 0.04 & 0.06 \\
\hline Surface area ( $\mathrm{nm}^{2} /$ molecule) & 2.3 & 25 & 10 & 5 & 50 & 25 & 16 \\
\hline $\begin{array}{l}\text { Distance between two molecules } \\
(\mathrm{nm})\end{array}$ & 1.5 & 5 & 3.16 & 2.23 & 7.07 & 5 & 4 \\
\hline
\end{tabular}

Table 3. Theoretical calculation of coating characteristics of nanocapsules as a function of DSPE$\mathrm{mPEG}_{2000}$ and $\mathrm{F} 108$ polymer concentration at their surface. 


\section{Figure Captions}

Figure 1. Encapsulation efficiency of DNA in LNCs and schematic representation of the different DNA

LNCs. The influence of coating on encapsulation efficiency was tested for all types of DNA LNC suspensions: DSPE-mPEG 2000 -coated (lanes 4 to 9) and F108-coated DNA LNCs (lanes 10 to 15). No migration of DNA into the gel indicates an efficient encapsulation. DNA molecules can not migrate once encapsulated in nanocapsules (lane 2), contrary to free DNA (pCMVluc) (lane1). The incubation of nanocapsules with $\operatorname{Triton}^{\circledR} \mathrm{X} 100(+\mathrm{T})$ led to the release of DNA molecules that migrated into the gel (lanes 3,5,7,9,11,13 and 15).

Figure 2. Particle cytotoxicity assessed by the MTT test. THP-1 cells were confronted with different formulations : free DNA, free lipoplexes, DNA LNCs, 5mM DSPE-mPEG 2000 and 2mM F108-coated DNA LNCs, at different concentrations of pDNA: $44.6 \mu \mathrm{g}, 4.46 \mu \mathrm{g}$, and $0.46 \mu \mathrm{g}$ per well. Cells without treatment were taken as the reference $(100 \%)$. As a control, empty LNCs were added at the same concentration (mg of LNC components per $\mathrm{ml}$ ) of DNA LNCs. Results are expressed as the percent of the optical density of the cells alone, as the mean \pm SD of 3 wells in 2 independent experiments. ${ }^{* *}: \mathrm{P}<0.01$ (Dunnett test).

Figure 3. Quantitative fluorescent confocal microscopy of living THP-1 cells exposed to fluorescent Dillabelled blank LNCs (i), DNA LNCs(ii) and coated DNA LNCs with DSPE-mPEG 2000 (iv) and F108 (v). The different Dil-labelled suspensions were incubated with differentiated THP-1 macrophages for $20 \mathrm{~min}$ at $37^{\circ} \mathrm{C}$. After extensive washes, cells were labelled with Syto60 red stain and images were acquired using an automated, confocal, fluorescence microscope. Representative pictures are shown in panel A. Dil-labelled vesicles can be seen in green. Note the important internalisation observed with non-coated DNA LNCs (iii) and F108-coated DNA LNCs (iv) whereas really small amounts of DNA LNCs coated with DSPE-PEG $5 \mathrm{mM}$ are detected. Images span $0.450 \times 0.340 \mathrm{~mm}^{2}$. Image-based quantification of the number of LNC-containing vesicles is displayed for serial 2fold dilutions of each LNC type (panel B).

Figure 4. Influence of DSPE-mPEG 2000 (A) and F108 (B) on complement consumption by DNA LNCs. The $\mathrm{CH} 50$ consumption was represented as a function of the nanoparticle surface area $\left(\mathrm{cm}^{2}\right)$ representing an increase in nanocapsule concentration. Suspensions of nanoparticles were incubated for $60 \mathrm{~min}$ at $37^{\circ} \mathrm{C}$ in human se rum diluted $1 / 4(\mathrm{~V} / \mathrm{v})$ in $\mathrm{VBS}^{2+}$. Complement consumption was evaluated as the lytic capacity of the serum (amount of CH50 units) towards antibody-sensitised sheep erythrocytes after exposure to blank LNCs, DNA LNCs and DNA LNCs coated with different concentrations of DSPE-mPEG 2000 (A) and F108 (B). Each datum point represents the group mean \pm s.d. of the $\mathrm{CH} 50$ units consumption.

Figure 5. Kinetic blood profiles of LNCs coated with various concentrations of DSPE-mPEG 2000 (A) or F108 (B) following systemic injection in Swiss mice. The percentage of injected dose (3.35mg of DNA/kg of animal 
weight) remaining in plasma following a single bolus injection is displayed as a function of time. Administration of empty LNCs and DNA LNCs are shown as a control. Each datum point represents the group mean \pm s.d. of the percent injected dose.

Figure. 6 In vivo fluorescence imaging of athymic nude mice bearing U87MG tumors after intraveinous injection of DNA LNCs or DSPE-mPEG ${ }_{2000}$ coated DNA LNCs. Optical images of nude mice with $152 \mathrm{mg} / \mathrm{ml}$ tail vein injection of DNA LNCs or DSPE - mPEG 2000 coated DNA LNCs (representing 46ug of pDNA per mice). Coloured bar on the left or upper part of the picture indicates the signal efficient of the fluorescence emission coming out from the animal. The tumor location is specified with a white arrow. 


\section{Table captions}

Table 1. Influence of the incorporation of DSPE-mPEG 2000 and F108 at the surface of DNA LNCs on size, polydispersity and zeta potential. Results show the mean \pm SD of at least 4 independent formulation measurements and 3 measurements per sample.

Table 2. The main pharmacokinetic characteristics of various formulations of LNCs after a single i.v injection in Swiss mice. Plasma clearance of the LNCs was measured over a 24h period in animals treated with $3.345 \mathrm{mg}$ of DNA $/ \mathrm{kg}$ of mouse weight. The half lives were calculated as follows: $t_{1 / 2}=\log (2) / L z$. The $L z$ was determined from linear regression using defined intervals (respectively $5 \mathrm{~h}$ and $24 \mathrm{~h}$, for $\mathrm{t}_{1 / 2}$ distribution [0-5h], and $t_{1 / 2}$ elimination [0-24h]). The AUC was calculated following the trapezoidal rule during the whole experimental period (1min to $24 \mathrm{~h}$ ) without extrapolation. The mean residence time was calculated from $1 \mathrm{~min}$ to $5 \mathrm{~h}$, from the following equation: MRT [0-5h] = AUMC [0-5h] / AUC [0-5h]. Each datum point represents the group mean \pm s.d.

Table 3. Theoretical calculation of coating characteristics of nanocapsules as a function of DSPE$\mathrm{mPEG}_{2000}$ and $\mathrm{F} 108$ polymer concentration at their surface. 